\title{
DOS NUEVAS LECTURAS DEL BARROCO ${ }^{1}$
}

\author{
POR \\ Antony HigGins \\ University of New Mexico, Albuquerque
}

El papel que ha jugado el "Barroco de Indias" en la formación de las culturas y de las identidades latinoamericanas vuelve a ser un tópico fundamental, hecho que se demuestra en dos libros nuevos. En Celestina's Brood Roberto González Echevarría busca reconstruir el Barroco como un discurso transhistórico que liga la tradición literaria hispanoamericana con un origen español barroco. Relecturas del Barroco de Indias, colección de ensayos de críticos diversos reunida por Mabel Moraña, por contraste, propone historizar el fenómeno del Barroco. Parte de la hipótesis de que la estética barroca asume una cara doble en América, por ser un discurso importado que los intelectuales criollos adoptan con el paso del tiempo para establecer las bases de una cultura diferenciada del modelo europeo.

Celestina 's Brood reúne una colección de ensayos de diverso origen, encuadrándolos en el esquema de una genealogía del Barroco hispánico. En su prefacio el crítico cubano explica la preocupación central del libro, la cual queda implícita en su título: "[t]he essays in this book are concerned with two general issues: modernity in the Hispanic literary tradition and the Baroque as the expression of the modern". (4)

El libro empieza con un análisis de la Celestina, texto que el autor recupera como obra fundacional de la literatura española. Explica la inserción anacrónica de la obra dentro del cuadro del barroco en los términos siguientes: "Celestina is not baroque, to be sure, but the fact that some of the most daring Latin American works today have gone back to it signals that Rojas's work is the point at which what they consider akin to them began" (4). Para González Echevarría la Celestina es uno de los primeros textos en que se realiza lo que él considera ser el papel fundamentalmente moderno de la literatura, esto es, el de socavar los conocimientos tradicionales o aceptados de una sociedad (31). Hace resaltar el tono nihilista de la obra, en la medida que los códigos más autorizados de la sociedad peninsular de la temprana modernidad se ven desmantelados mediante la actuación de la alcahueta. Apunta la tensión constante que existe entre el nivel metafórico del lenguaje sobre todo en el discurso degradado del amor cortesano que enuncia Calisto- y el uso más literal o desmistificador —aunque también figurativo— de los personajes que

\footnotetext{
'Roberto González Echevarría. Celestina's Brood. Continuities of the Baroque in Spanish and Latin American Literature. Durham: Duke University Press, 1993; Mabel Moraña, ed. Relecturas del Barroco de Indias. Hanover: Ediciones del Norte, 1994.
} 
representan las clases populares (16-27). Establece un nexo entre esta problemática de representación y el hecho de que ciertos personajes bajan de un nivel social a otro, sobre todo en el caso de la muerte de Calisto, quien cae de un lugar alto - la torre- al de una materialidad mundana - la tierra (17-19). Según el crítico cubano-americano, Celestina se identifica por su habilidad retórica. Al ocupar el espacio mediador de la comunicación simbólica, ella es una figura que encarna las complejidades del lenguaje. La identificación Celestina-lenguaje figurativo funciona en torno a la correspondencia que el autor quiere ver entre un comportamiento que conduce a la (auto)destrucción de un sistema de relaciones socio-simbólicas y una visión desconstructivista del lenguaje como un medio problemático que no representa ninguna presencia real de modo transparente y que es una superficie vacía que distorsiona las realidades materiales (26-27). Partiendo de esta premisa, se aboca a la tarea de consignar la recuperación hispanoamericana de los motivos de la Celestina, texto que, según él, ha sido suprimido por la crítica española por representar la búsqueda del placer sensual y el desmantelamiento de los sistemas de valores de su época - en efecto, así consigue crear una imagen engañosa, puesto que, a nuestro parecer, la Celestina es, después del Quijote, el texto más estudiado del hispanismo peninsular. Analiza las maneras en que varios novelistas latinoamericanos han rescatado ciertos elementos de la obra (33-35). Sostiene que la figura de la alcahueta ha sido transformada en un rico generador de intertextos, el más interesante de los cuales es la exploración que realiza Sarduy sobre la sexualidad en Cobra, texto al cual vuelve en el último capítulo del libro (42-44).

"The Life and Adventures of Cipión: Cervantes and the Picaresque" es una versión amplificada de una reseña que González Echevarría escribió sobre el libro de Harry Sieber, Language and Society in "La vida del Lazarillo de Tormes" (1978). Sieber sostiene en este libro que la clave de la relación problemática del género con su contexto es una cuestión de lenguaje (50). Dentro de un contexto histórico donde la escritura iba adquiriendo más importancia, al expandirse las burocracias y desarrollarse la literatura como práctica de formación de "letrados", la picaresca debe verse como una actividad performativa, un medio a través del cual un sujeto pequeño-burgués se adapta a los códigos que rigen la sociedad española del siglo XVI (50-53). A modo de ejemplo, González Echevarría analiza la manera en que Cervantes concibe la autobiografia. Es otro caso en que una articulación moderna y modernizadora de la literatura se liga a la práctica de socavar un código autorizado. Se trata del cuestionamiento de la pretendida veracidad del relato autobiográfico que Cervantes lleva a cabo en las dos novelas ejemplares conectadas, "El casamiento engañoso" " "El coloquio de los perros." Considera que Cervantes quiere reflexionar sobre la emergencia de la autobiografia como género legítimo, parodiándola al armar un diálogo en que dos pícaros se transforman en perros, los cuales explican cómo llegaron a hablar (60-63). Según él, esta tendencia a parodiar elementos de discursos orgánicos de autoridad, y reunirlos de modo heterogéneo, demuestra el carácter barroco y moderno de la narrativa de Cervantes, y de la novela como género compuesto que rompe con toda noción de modelos, con los criterios clásicos de la unidad y del decoro (64-65).

Siguen tres ensayos sobre el fenómeno de la comedia barroca. "Poetry and Painting in Lope's El castigo sin venganza" estudia una problemática que deriva del carácter inequívoco de la exploración lopesca de la relación compleja que liga el amor al honor. El 
crítico inserta el texto de Lope dentro de su esquema de una modernidad barroca hispánica a dos niveles. Primero, ve en el vaivén turbulento y trágico entre el amor personal del duque por su hijo y la proyección del deber en el orden social el eje del teatro barroco español, en tanto representación de los problemas involucrados en la actuación del individuo en un espacio ya público y común, no parcelado (80). En segundo lugar, la obra debe ser vista dentro del contexto de la lucha con Calderón y otros por el prestigio cultural. Por eso, una incipiente ansia de originalidad ha influido en la composición de la pieza para producir una investigación ambivalente de los temas del amor y del honor.

La conceptualización del Barroco en tanto expresión de un dinamismo estético y social es también un tema que el autor explora en dos ensayos sobre La vida es sueño. "Calderón's La vida es sueño: Mixed-(Up) Monsters" analiza el personaje de Segismundo a fin de estudiar el papel de la figura del monstruo como emblema de una estéticą que surge de una emergente autoconciencia creativa del escritor español y frente a la necesidad de sorprender a un público teatral sofisticado (82). Es un momento en que el cambio y la combinación ya son los principios básicos de un teatro que sobrepasa los parámetros del clasicismo (87-95). También sitúa estas imágenes monstruosas dentro del contexto imaginario producido por el primer contacto del europeo con los animales y las plantas americanas (101-02) y por la incorporación de las personas deformadas a las formas de diversión que se montaban en los palacios (102-09). No obstante, en Calderón se trata sobre todo de una reflexión sobre la relación del artificio con la naturaleza, la cual conduce a una práctica de la representación del mundo material en que prima la noción de que necesariamente la búsqueda de la perfección produce también la imperfección (97-98; 111-13).

“Threats in Calderón. La vida es sueño. 1: 303-8," estudia los seis versos referidos del primer acto de la obra de Calderón, fragmento en que Clotaldo halla que Rosaura y Clarín han descubierto el lugar donde el rey ha escondido a Segismundo y les amenaza de modo ambiguo. Partiendo de un análisis filológico de la traducción de los versos al inglés, el crítico sostiene que la estructura rebuscada de la amenaza resulta de varios elementos del teatro barroco, entre ellos la relación con los refranes derivados del árabe y con el habla de los mosqueteros que asistían a las comedias (119-22). Por encima de todo, percibe en esta frase la encarnación del proceso mediante el cual la literatura imaginativa se establece como discurso propio que ocupa un lugar discreto dentro de una red ideológica moderna. En primer lugar, la amenaza también surge de la lucha trabada entre los dramaturgos por la primacía (122). En segundo lugar, constituye un tipo de lenguaje performativo que funciona no sólo a un nivel denotativo sino que realiza, a la vez, el acto de su propia constitución en tanto estructura que produce un efecto de asombro en la mente del espectador (sin mencionar la relación, se acerca aquí a la conocida tesis sobre la función ideológica del teatro barroco de José Antonio Maravall).

"Reflections on the Espejo de paciencia " sirve de puente entre las letras españolas e hispanoamericanas al tratar el poema épico escrito en Cuba por el canario Silvestre de Balboa y Troya y Quesada en 1608. El crítico enfoca la recepción que el poema ha tenido entre varias generaciones de escritores cubanos desde el momento en que José Antonio Echeverría lo recupera en 1838 (132). Traza una genealogía de intelectuales que han convertido el texto de Balboa en pieza fundacional de la literatura cubana (133-43). 
Demuestra las maneras en que la mayoría de estas lecturas distorsiona el poema, viéndolo como cuadro transparente de la naturaleza cubana. Ilustra cómo esta interpretación "esencialista" tiende a suprimir el hecho de que el poema reúne - como sugiere su mismo título- imágenes dispersas en la medida que representa tanto los artefactos importados como los elementos indígenas de la naturaleza cubana. De este modo, desde el momento de su concepción la obra es un todo artificioso, caótico e híbrido, el cual se coloca al lado de los emblemas retorcidos de la arquitectura, la pintura y las ceremonias públicas que llegaron a constituir el Barroco colonial (144-46).

El ensayo "Poetics and Modernity in Juan de Espinosa Medrano, Known as Lunarejo," quizás la pieza clave de la colección, continua el tema de la relación de una "hibridez" barroca con la "originalidad" americana. González Echevarría se empeña en desplazar la imagen que la historiografia literaria latinoamericana ha construido en torno al Lunarejo como escritor mestizo pobre (149-50). Sustituye esta imagen con la figura del "señor barroco" descrita por Lezama Lima, esto es, un sujeto intelectual criollo protohegemónico que emerge durante el período de la estabilización colonial y que ya siente un arraigo al territorio americano. Espinosa Medrano así representa el tipo de letrado criollo que ya posee una formación intelectual que le permite reflexionar sobre su propia identidad y sobre la poética desde una situación de autonomía relativa. Para el autor de Celestina's Brood, el Apologético a la vez reivindica una poética moderna - la gongorina - y articula el discurso de una identidad americana sobre la base de esta poética dinámica e híbrida (151-53). Al cultivar un estilo en que se busca asombrar mediante las combinaciones extrañas que transgreden las normas humanistas, el criollo crea una especie de espejo roto en el cual puede reconocerse. Recordando el tema de la monstruosidad en Calderón, el crítico hace resaltar la idea de que la defensa de la expresión gongorina se liga a la investigación del carácter de la experiencia criolla, al sentirse como monstruo que siempre existe en una relación de retardo con respecto a Europa y que debe articularse desde dentro de un discurso europeo que marca al americano como bárbaro (154-59). El Barroco colonial es el discurso mediante el cual el criollo puede dar una legitimidad a esta identidad deformada - de que el lunar de Espinosa Medrano es símbolo- al expresarla en esta poética en que se transforma el principio de imitatio y que crea tropos extraños, un lenguaje que llama la atención al lector no sólo por las ideas que expresa sino por su carácter estilizado (161-69). De este modo, se identifica el discurso del Barroco como algo que se articula de modo ambiguo al proyectar la formación de esferas culturales autosuficientes cuyos sujetos se sienten modernos y atrasados a la vez.

Saltando tres siglos - algo que hace dudar la suposición de la continuidad del Barroco en la cultura latinoamericana - "Socrates Among the Weeds: Blacks and History in Carpentier's El siglo de las luces " coloca la obra referida dentro del marco de la problemática postcolonial en torno a la manera en que se ha suprimido la contribución del sector africano a la historia de la América hispánica. González Echevarría destaca a Carpentier por haber representado la presencia africana en sus novelas no sólo a través de los personajes individuales sino por medio de la evocación de una actuación masiva y social (172-73). Enfatiza los modos en que Carpentier ficcionaliza las prácticas con que los afrocaribeños contribuyen a la realidad cubana a fin de producir un todo en que se transgreden las fronteras entre lo europeo y su "otro". En El siglo de las luces se representa la historia cubana como 
algo que traspasa la concepción ilustrada de una narrativa del progreso continuo y que se despliega más bien de acuerdo con la lógica del sincretismo, metáfora encarnada en la figura del busto de Sócrates que se halla en un jardín lleno de plantas cubanas (173-76). Carpentier dibuja un espacio americano que surge de una especie de reorganización anagramática de la realidad mediterránea, fenómeno que se manifiesta en la inversión de la lógica liberadora de la revolución francesa (181) y en los cambios lingüísticos (186). Para González Echevarría la figura retórica barroca por excelencia, el quiasmo, o el retruécano, es la cifra maestra que expresa esta realidad "otra", híbrida, en que no puede establecerse una jerarquía entre sus componentes, ni en la esfera del valor ni en la del tiempo (181-82).

"Guillén as Baroque: Meaning in Motivos de son" vuelve a explorar los límites de la imagen que la crítica ha elaborado en torno a un escritor. Aquí se trata del papel de "voz" del negro que la crítica cubana ha impuesto a Nicolás Guillén (194). González Echevarría reenfatiza, en contraste, la importante labor que Guillén realiza al recuperar la estética gongorina (195-98). Pretende demarcar una diferencia entre una estética barroca que se abre a la otredad - Góngora es uno de los primeros en escribir versos en que se imita el español hablado de los negros - y otra, renacentista, que lo mantiene siempre a distancia (197-98). Aquí la clave es el carácter público del Barroco colonial, elemento que Guillén retoma en Motivos de son para incitar a la sociedad cubana a reflexionar sobre la represión de su componente negro (201-04). Mediante una exposición cuidadosa el crítico demuestra que el lenguaje aparentemente musical y sencillo de los poemas - para la crítica blancacontiene ideas complicadas y ambiguas emitadas en una sintaxis que reelabora los giros sensuales de la poesía barroca (204-10).

El último ensayo de Celestina's Brood, "Plain Song: Sarduy's Cobra," traza cómo la obra del escritor cubano continúa, con ciertos cambios, el pensamiento de Lezama Lima, según el cual el Barroco es un sistema monista transhistórico que le permite a un sujeto poético reunir tópicos e imágenes de tiempos y espacios diversos en el signo de la metáfora (213-17). Para González Echevarría, es Sarduy quien ha investigado de modo más satisfactorio la noción de que este signo barroco constituye el origen de la conciencia hispanoamericana al haber penetrado más allá de la tesis del "Barroco de Indias" formulada antes por Alfonso Reyes, Pedro Henríquez Ureña y Mariano Picón Salas (218). Sus conocimientos del estructuralismo y del freudismo llevan a Sarduy a producir una narrativa radical en que se rechaza toda concepción esencialista de la identidad para proyectar un mundo semiótico donde prima una lógica metafórica que se mueve entre los actos de "vaciar" y "llenar" las distintas formas de la subjetividad (219-20). De este modo, se rompe con la tradición según la cual la identidad latinoamericana es basada en su capital geográfico, o su "naturaleza", sustituyéndola con una lógica semiótica para la cual los orígenes de todo sujeto son múltiples (232-34). En Cobra se ve la identidad como algo que siempre está en proceso de construirse, en este caso en el área del género sexual, que se desmantela y fabrica a través del travestismo y de la cirugía (221-25; 236-37). En este sentido, si el Barroco constituye para González Echevarría el origen de una modernidad propiamente hispánica y americana, también es el modelo de su futuro. Cabe recordar que dicha tesis halla su contrapunto en la observación de Leonardo Acosta que el Barroco fue "un fenómeno estrictamente europeo" y que las nuevas formas artísticas en América Latina probablemente "en una serie de aspectos serán todo lo contrario del Barroco" ("El Barroco americano y la ideología colonialista," Unión 11, 2-3 (1972), 59). 
La mayoría de los colaboradores de Relecturas del Barroco de Indias trata de repensar la problemática del Barroco americano dentro del panorama teórico establecido a la luz de la investigación realizada por José Antonio Maravall sobre el Barroco español y del debate sobre el tópico de la crítica latinoamericana. Como señala la coordinadora en su introducción, todos los trabajos se remontan, de alguna manera, a las intervenciones anteriores realizadas por Mariano Picón Salas, Alfonso Reyes y Pedro Henríquez Ureña, quienes plantearon y desarrollaron el concepto del "Barroco de Indias" durante los años cuarenta y cincuenta (xii). No obstante, sus autores también se preocupan por explorar dicho tópico desde nuevas ópticas y por darle una serie de matices precisos a un concepto de época o de estilo que a menudo se ha manejado como una figura monolítica y borrosa.

La relación con esta generación previa se establece en el ensayo "Para una teoría de un Barroco hispanoamericano," de Alfredo Roggiano. En una reformulación de su tesis clásica sobre el Barroco americano, el crítico argentino propone una resolución del conflicto entre los que quieren utilizar el Barroco como un concepto de época y los que lo manejan como un style concept (1). Postula una síntesis que convierte el barroco en una especie de visión estética del mundo: "una poiesis que se realiza como parte de la función del ser en su mundo, en un tiempo y espacio que le da su génesis y lo condiciona" (2). De este modo, resulta posible hablar de barrocos diversos que varían de acuerdo con el contexto nacional y religioso del que surgen.

Dentro de este esquema, Roggiano describe la trayectoria del Barroco americano mediante la reconstrucción de una narrativa que comprende tres etapas (5). Durante la primera fase, que empieza con la emergencia del estilo plateresco a mediados del siglo XV y dura hasta fines del XVII, el Barroco es una estética "culta" que al principio se rechaza en España por ser vista como algo foráneo, no castizo, para luego convertirse en modalidad aceptada, de acuerdo con una concepción más universalista de la cultura (6). En la segunda fase, la poética barroca llega a América como discurso de contrabando al haberse prohibido la transmisión a la Colonia de obras escritas en estilo culterano (6-9). Es en la tercera fase que una emergente clase criolla desarrolla su propia variante del Barroco durante la segunda mitad del siglo XVII y en la primera mitad del XVIII, período en que este discurso se ve desplazado en España (9-10). Mediante esta genealogía se funde una fenomenología americana, una visión expresionista y sensualista del mundo, el cual se remonta a las formas creativas prehispánicas y se proyecta hacia los discursos culturales del siglo XX, sobre todo el realismo mágico. De este modo, se constituye una estética que no se basa en la mímesis clásica sino en la noción de lo disímil que se fomenta a raíz de la transmisión del estilo gongorino y del gusto por los efectos de extrañeza que produce (10-11).

El trabajo de Roggiano articula, como el libro de González Echevarría, otra variante de la tesis de que el Barroco americano ya es el discurso a través del cual se expresa por primera vez una voz americana propia. En varios otros trabajos de Relecturas, sin embargo, se busca cuestionar los fundamentos y las premisas que sostienen esta tesis. John Beverley, en "Gracián o la sobrevaloración de la literatura (Barroco y postmodernidad)," postula que el debate sobre el Barroco americano brota por ambos lados de una ideología que apuntala la práctica literaria en Latinoamérica y según la cual se sobreestima la importancia del papel que juega la literatura dentro de la praxis social general (17-18). Para Beverley, ésta es una ideología cuya trayectoria americana empieza al diseminarse la 
estética barroca en la Colonia. De acuerdo con la formulación que da Gracián de esta estética en su Agudeza y arte de ingenio, la literatura imaginativa no sería tanto la imagen o "representación" del poder sino su encarnación misma al producir efectos de asombro y de sumisión en el público mediante el ejercicio del ingenio y su articulación ceremonial (18-22). Dando otra interpretación al tema de crisis de los códigos lingüísticos sugerido por González Echevarría, Beverley cree que Gracián aboga por un tipo de literatura en que se enfatiza la forma por encima de la función referencial o doctrinal del lenguaje. No sirve para representar un contenido sino para posibilitar el "ejercicio" del intelecto y, de allí, la proyección y el manejo del poder (24-25). Este programa se articula en un momento en que la figura social del guerrero y el género de la épica se habían convertido en anacronismos. Gracián demuestra que para mantener la hegemonía artistocrática se necesitaba otro sujeto social —el discreto o el político-, que se asemeja paradójicamente al tipo moderno del genio literario que se articula y expresa dentro de una ideología de la autonomía estética (26). Este sujeto no escribe géneros sublimes - como la épica- sino formas menores, como los romances, los sonetos “ocasionales", los villancicos, las loas y las letrillas satíricas del Gongorismo colonial. Beverley termina por plantear que este discurso de lo literario, el cual se otorga para sí mismo una autoridad sublimada en el ámbito sociocultural, es una "técnica de poder" no sólo de la clase señorial española y virreinal de principios del siglo XVII sino también dentro de "la práctica académica de las humanidades hoy" (27). Por eso, concluye (en una respuesta tácita a la tesis de González Echevarría) que para ahondar más en la investigación del "fenómeno del Barroco en América Latina" hace falta que la crítica desarrolle, al mismo tiempo, una indagación historicista y desconstructivista sobre "la ideología (humanista) de lo literario" (27) que moldea su propio quehacer.

Dicha ideología asume una doble faz en la Colonia. En "Apologías y defensas: discursos de la marginalidad en el Barroco hispanoamericano" Mabel Moraña plantea los términos de esta problemática. En un mundo virreinal compuesto de una mayoría analfabeta y de una minoría que maneja el poder debido —en parte- a su dominio retórico del lenguaje, se destaca el espacio cultural de la ciudad letrada, en que se debate y se determina la organización de la sociedad. Al mismo tiempo, el proceso a través del cual se conceptualiza la visión de un mundo diferenciado del europeo también se realiza dentro de este mismo espacio. Moraña insiste en señalar que estas circunstancias proveen el marco desde el cual los criollos cultos empiezan a formular un discurso de y sobre la diferencia, todavía dentro de los parámetros de la estética canónica del Barroco (44-46). Mostrando una preocupación por las condiciones del performance y de la recepción públicos de los textos - factor que González Echevarría tiende a suprimir en sus análisis-Moraña subraya la importancia de los géneros del panegírico y de la defensa en una sociedad donde la relación entre las instituciones eclesiásticas y la producción de conocimientos era muy estrecha (33-36). Al manejar estos géneros religiosos y legales, el intelectual criollo asimila uno de los recursos mediante los cuales se consolidaba la unidad del orden colonial, esto es, el acto de producir en la mente del oyente inculto un efecto de sumisión estupefacta ante el ingenio y el espectáculo del discurso. Al mismo tiempo, se enaltece la producción literaria americana al insertarla en el marco de un panorama "universal" en obras como el Discurso en loor de la poesia, de una mujer peruana anónima, y el Compendio apologético, de Bernardo Balbuena. En tales textos el letrado criollo insinúa un subtexto que articula la 
conciencia de una condición diferenciada, enmascarada e incorporada entre los recursos retóricos del elogio del orden imperial y de la falsa modestia (36-37). Otro factor en la articulación de una "criolledad" diferenciada que la crítica uruguaya destaca es la noción del "retardo americano", efecto del lapso que suele existir entre el tratamiento de un tópico en Europa y la trayectoria específica que éste sigue en América (40-41). De acuerdo con esta circunstancia, el hecho de que Sor Juana escriba su Carta atenagórica unos cuarenta años después del sermón de Vieira. el cual critica, se revela como un elemento definitorio que el sujeto criollo asume conscientemente en tanto anacronismo que marca la separación entre el espacio virreinal y la metrópoli (41-43). Moraña termina por proponer que tanto en el texto de Sor Juana como en el Apologético de Espinosa Medrano, la defensa de lo "otro" y su incorporación a un discurso utópico, esto es, al elogio, todavía dentro de los parámetros de la escolástica y del absolutismo imperial, son prácticas simultáneas mediante las cuales el Barroco se extiende y descentraliza desde la metrópoli hasta la periferia americana (44-48).

La investigación de una coyuntura cultural en que los sujetos americanos articulan nociones de su propia especificidad todavía dentro del marco institucional imperial, y de acuerdo con los patrones culturales establecidos por dicho marco, es un tópico que retoma Georgina Sabat-Rivers en el ensayo "El Barroco de la Contraconquista: primicias de conciencia criolla en Balbuena y Domínguez Camargo." Sabat-Rivers se propone rastrear los textos de estos dos escritores para trazar la presencia de tres características que Maravall destaca por ser fundamentales al Barroco hispánico: las fuertes contradicciones, la visión política y maniqueísta de la experiencia humana, la ciudad capital como ente dominante (60). Identifica a Balbuena y a Domínguez Camargo como figuras que desarrollan sus carreras en estrecha relación con el poder de los centros administrativos virreinales, lo cual se hace más evidente en los poemas en que elogian la urbe, la Grandeza Mexicana y "Al agasajo con que Cartagena recibe a los que vienen de España" (70-71). Sabat-Rivers observa que Balbuena sigue las reglas del canto al imperio al evitar la representación de todo aspecto negativo de la ciudad de México, pero al mismo tiempo proyecta el auge de la urbe periférica, justo en un período cuando Madrid y España están en el declive, y se reconoce el derecho del indígena sobre sus tierras (71-73). Por su parte, Domínguez Camargo también busca incorporar a su poesía una imagen de la alteridad americana, aunque se mantiene fiel a la convención de expresarla por el medio del estilo culterano en el Poema Heroico (1666) que le dedica a Ignacio de Loyola (73). Sabat-Rivers enfatiza el hecho de que en dicha obra se reivindica al Inca, el saber aritmético y la valentía de los indígenas, y lamenta la Conquista y la codicia (73-75). De este modo, establece un discurso de la diferenciación con respecto a los intereses peninsulares.

El carácter jánico de la práctica literaria criolla durante el siglo XVII también se explora en dos trabajos dedicados a la obra de Espinosa Medrano, que ofrecen un contrapunto interesante al ensayo que González Echevarría dedica a esta misma figura en Celestina's Brood. En "La subversión del Barroco en Amar su propia muerte de Juan de Espinosa Medrano" Raquel Chang-Rodríguez analiza la dualidad de la escritura del autor criollo tal como se revela en dicha obra teatral. Subraya la noción de que Espinosa Medrano cultiva la cultura humanista y escolástica, tal como se transmitía en la jesuita Universidad de San Ignacio de Loyola — donde estudió el Lunarejo- con la esperanza de que sus 
conocimientos le facilitasen el éxito dentro de las instituciones virreinales (117-18). No obstante, sus proyectos acaban por verse frustrados al cerrársele el paso a los puestos importantes debido a su ascendencia criolla o mestiza (118-21). Chang-Rodríguez coloca Amar su propia muerte dentro de la problemática de la inserción de componentes americanos en los sistemas de representación coloniales. Subraya cómo se establece un discurso diferenciado por su heterogeneidad en este texto, sobre el cual se especula que debió haberse estrenado en los claustros de la universidad durante la época en que se formó el joven Lunarejo. Indica las maneras en que el texto combina los fundamentos del teatro español - el conceptismo, la ruptura de las unidades clásicas, la trama en torno a la cuestión del honor, la temática bíblica-, con una serie de elementos andinos - las referencias a la vida difícil de los indígenas que trabajan en las minas; un sueño que deriva sus imágenes de la cultura indígena; la presencia de dos personajes femeninos cuya actuación tiene connotaciones de resistencia indígena (129-36).

José A. Rodríguez Garrido analiza los mecanismos de este mestizaje semiótico en los textos explícitamente religiosos del Lunarejo en "Espinosa Medrano, la recepción del sermón barroco y la defensa de los americanos." Critica la noción de que en las letras hispanoamericanas de los siglos XVI y XVI se reproducen los modelos europeos sin que haya ninguna reflexión sobre las injusticias y las contradicciones culturales que surgen de la experiencia colonial (149). El Lunarejo encarna el tipo de sujeto americano culto que discierne en los discursos europeos - como el Culteranismo- las herramientas que necesita manejar para participar activamente en la producción de la cultura universal y en los ideales universalistas del imperio (150). El estilo gongorino se presta al uso particular del americano no sólo por estar involucrado en la fabricación metáforica de imágenes anómalas y excéntricas sino también por ofrecer un medio para constituir una subjetividad dotada de artes transcendentes y legitimadoras (151-52). Rodríguez Garrido se concentra en la práctica del sermón, actividad a la cual se dedicaba Espinosa Medrano, además de las letras humanas. Retomando la problemática del performance y de la recepción de los textos, el crítico peruano destaca la manera en que este género funciona en la Colonia en dos niveles, por un lado, dirigiéndose al público erudito de los letrados (153-54), y, por el otro, captando ideológicamente a la mayoría analfabeta mediante la delectatio, efecto de asombro que infunde sobre el público el espectáculo de la elocuencia (155-56). El caso de un sermón que el Lunarejo pronuncia sobre Santa Rosa, patrona del Perú, sirve para demostrar las estrategias que su autor utiliza para reivindicar la subjetividad americana al aludir a la posibilidad de que dicha figura pueda tener una presencia dentro del sistema universal de la Iglesia católica (156-59). Rodríguez Garrido discierne cómo Espinosa Medrano inserta en este sermón una defensa de la inteligencia y de las capacidades del intelectual hispanoamericano, un subtexto codificado de tal manera que pudiera entenderlo el sector americano del público letrado (164-67).

La doble voz del letrado americano del virreinato es una cuestión que trata también Kathleen Ross en el trabajo "Carlos de Sigüenza y Góngora y la cultura del Barroco hispanoamericano." La investigadora norteamericana ofrece una relectura de las imágenes reduccionistas que los historiadores y los teóricos del Barroco americano han impuesto al criollo novohispano al armar el cuadro de las letras coloniales (223-24). Subraya la necesidad de tener en cuenta las ideologías que motivan las interpretaciones críticas de la 
obra de Sigüenza y Góngora. Demuestra cómo una perspectiva ilustrada lleva a Irving Leonard y a Mariano Picón Salas a representar a Sigüenza y Góngora como figura que lucha contra las supersticiones de su época sin liberarse del gusto por un modo de expresión innecesariamente complicado (224-30). Con agudeza Ross desmantela la lógica del discurso liberal en las interpretaciones que ofrecen José Lezama Lima y Octavio Paz al reconstruir a Sigüenza como defensor de la creatividad individual frente a fuerzas sociales opresivas y como artista que maneja el discurso barroco de tal modo que pueda comunicar la complejidad y el caos de la experiencia hispanoamericana (230-33). También analiza a los críticos que estudian a Sigüenza y Góngora a la luz de la obra de Maravall. Según Ross, éstos caracterizan al criollo como un "producto" de la cultura literaria imperial. Dentro de este esquema algunos hallan en la escritura de Sigüenza y Góngora la expresión de una incipiente noción de la diferenciación americana (233-36). Ross, en cambio, prefiere no colocar al criollo dentro de una dialéctica que se mueve entre los dos polos del Barroco y de la Ilustración, ni verlo como un marginado. Más bien, se propone analizar su obra a la luz de la reinterpretación que la historiografia económica ha hecho al rebatir la tesis clásica de que en la Colonia el siglo XVII fue una época de declinación. Ross ve en el conjunto de los textos de Sigüenza un discurso general sobre la historia, la geografía y el cambio social - lo que llama "historiografía criolla" - escrito en un período en que el poder económico de la elite criolla iba creciendo (236-39).

En una dirección parecida se mueve "Bases teóricas para una lectura ex-céntrica del discurso colonial de Juan Ruiz de Alarcón” de Alberto Sandoval Sánchez. Examina cómo las escuelas críticas dominantes han creado una imagen europeísta de Alarcón, rechazando los esfuerzos que han hecho Pedro Henríquez Ureña y otros investigadores por incorporar a este escritor al proceso de articulación de la literatura latinoamericana (282-85). Propone una contralectura que va aun más allá de los análisis realizados por Arrom y Concha, quienes se han enfocado sobre la "extrañeza" de la obra de Alarcón para interpretarla como la manifestación de una subjetividad burguesa criolla en gestación y, a la vez, como el enunciado de un extranjero trasladado desde la periferia al centro del imperio español (285-88). Así se discierne que la experiencia de hallarse desplazado hace a Alarcón vacilar entre el deseo de realizarse en la metrópoli y la conciencia de que nunca puede constituirse como reproducción mimética del modelo del "yo" imperial (288-94). Sandoval interpreta la falta de referencias a México en la obra de Alarcón como manifestación de una forma de subjetividad involucrada de modo interminable en el ejercicio de postergar la definición de una identidad fija.

En "La cultura barroca y el nacimiento de la conciencia criolla en el Brasil" Lúcia Helena Costigan explora la cuestión del carácter de la cultura criolla en el área de habla portuguesa durante la época colonial. Anota que la arquitectura barroca llega a ser parte de la cultura de la ostentación que practican los criollos brasileños en la primera mitad del siglo XVII. Señala, sin embargo, que la cultura literaria se desarrolla menos en el Brasil que en México y en el Perú, en gran medida debido a la falta de universidades y de imprentas, y también a consecuencia de la política portuguesa que prohibe a los criollos ser jueces o magistrados del Tribunal Supremo a partir de 1670 (303-09). Costigan divide a los letrados criollos del Brasil colonial en dos grupos. La mayoría —entre ellos, Bento Teixeira, Manuel Botelho de Oliveira y Antonio Vieira - escriben en un estilo culterano, siguiendo 
fielmente los modelos europeos y reivindican los intereses de los nobles y de los burócratas portugueses a quienes dirigen sus obras (310-15). Otro tipo de letrado, que desarrolla una escritura más heterogénea y más atenta a los problemas de la Colonia misma, se ejemplifica en la figura de Gregório de Matos. Costigan hace resaltar el tono del desengaño barroco que marca su obra, expresión de una nostalgia a la vez contrahegemónica y reaccionaria por la sociedad oligárquico-feudal que los dueños de los ingenios habían presidido antes de verse desplazados a raíz de los efectos de la economía mercantilista (316-21). Más importante, sin embargo, es la manera en que Matos rompe con el Culteranismo para incorporar a sus textos los elementos de la conflictiva dialéctica colonial -el vocabulario africano, las palabras indígenas y las formas de expresión corrientes-, reuniéndolos en un todo que mezcla lo culto con lo popular y que transgrede las normas clásicas (321-24). Costigan enfatiza el hecho de que Matos inicia así un discurso contrahegemónico al representar esta heterogeneidad a pesar de que lo hace para marcar los efectos de la desintegración de su propia utopía.

Los otros ensayos de la colección se acercan a la investigación del Barroco en América desde una óptica distinta a los que tratan la cuestión del carácter doble del letrado criollo en tanto autor de una incipiente cultura diferenciada criolla que se aferra, no obstante, a los parámetros del saber escolástico y de la poesía culterana. En "La obra satírica de Sor Juana" Julie Greer Johnson trata la problemática de la configuración de la identidad femenina dentro de la sociedad colonial. Según la investigadora norteamericana, Sor Juana se sirve de los recursos paródicos del enmascaramiento y del travestismo para revelar el carácter de artificio de la feminidad y el papel hipócrita que desempeña el hombre en el proceso de su construcción (97). Greer Johnson apunta cómo Sor Juana desmitifica la supuesta dualidad de la mujer en la redondilla "Hombres necios" al demostrar que es una imagen discursiva que se produce a raíz de las expectativas irrealistas de los hombres (98-100). También traza las estrategias que utiliza la criolla para luchar contra la configuración patriarcal de lo femenino en la Respuesta a Sor Filotea de la Cruz. Anota la manera en que Sor Juana adapta el tono apologético y la práctica de la confesión - siendo ambos aparatos de control discursivo que el patriarcado ejerce sobre la mujer- al acto de crear un sentido de ambigüedad a través de las expresiones de agradecimiento y falsa modestia que dirige al obispo de Puebla (101-06). Subraya la noción de que la criolla mexicana se aprovecha de las estructuras de los códigos de la escolástica y de la poesía culterana para insinuar una forma de la subjetividad femenina distinta a la dominante, armando un discurso cuya flexibilidad y cuya complejidad le hace resistir todo esfuerzo por deshacerlo (107-11). De este modo, Greer Johnson cree ver en Sor Juana una ruptura con el esquema socio-simbólico establecido, en la medida en que constituye otro modelo discursivo del cual otras mujeres puedan servirse para resistir las reglas del orden patriarcal en el futuro (111-12).

La presencia de la simbología jesuita dentro de la cultura del Barroco americano es un tópico que explora José Pascual Buxó en el ensayo "Ignacio de Loyola y su influencia en la poesía hispanoamericana: el caso de Francisco Alvarez de Velasco Zorrilla." El crítico mexicano analiza los elementos que el escritor santafereño retoma de los Ejercicios espirituales en los poemas publicados en su Rhythmica sacra, moral y laudatoria (1703). Funcionario y ganadero, cultivó las letras sagradas y humanas, sobre todo la poesía, en la soledad de su hacienda, la cual estaba situada muy lejos de los centros urbanos (173-75). 
Buxó indica cómo el criollo sigue el modelo ignaciano al evocar una serie de imágenes terroríficas del pecado que se destacan por su viveza casi material en los poemas de la serie de los "Novísimos" (176-81). El crítico mexicano comenta la manera en la que dentro de los poemas se pasa de estas imágenes a un acto de contemplación mediante el cual el criollo resuelve y sublima las emociones desencadenadas por estas fantasías a fin de llegar finalmente a un estado de tranquilidad bajo el amparo de la figura de Cristo, de acuerdo con la lógica de los Ejercicios (182-84).

La cuestión de la relación entre la materialidad americana y el hipertextualismo de la cultura barroca se plantea de modo más teórico en el ensayo de Mario Cesareo, "Menú y emplazamientos de la corporalidad barroca". Cesareo conceptualiza el Barroco como una modalidad estética que surge del esfuerzo por teorizar y llevar a la práctica un orden unitario, el cual materializa, mediante la labor de las instituciones, la utopía cristiana de un paraíso terrenal (185). El crítico señala que la experiencia misionera transforma, desde la periferia, la configuración del cristianismo al enfrentarlo inexorablemente a la materialidad, realidad de la cual la Iglesia anteriormente había huido en el proceso de constituirse y de desarrollarse en Europa (185-86). La Iglesia se ve transformada en algo menos sólido, en algo contingente que debe luchar para realizar su proyecto ideológico con recursos insuficientes ante un espacio más arduo que el europeo (187-91). Frente a un tipo de sujeto indígena que se revela no como tabula rasa sino como una presencia que resiste a sus planes, el misionero se halla obligado a entrar en una relación de intercambio, de tal modo que él y las instituciones eclesiásticas sufren una transformación al ver al indígena como un ser humanizado por la experiencia del sufrimiento (191-93). De este modo, el cuerpo del otro se convierte en un espacio simbólico que ocupa un lugar central dentro de la teoría y de la práctica religiosa colonial, en la medida que es el sitio en donde el misionero busca reimponer el orden del discurso alegórico del cristianismo (193-95). Según Cesareo, Alonso de Sandoval, cura jesuita del siglo XVII, se inserta en esta problemática por haber dedicado gran parte de su vida a la catequización de los esclavos negros. Su obra, De instaurada Aethiopium salute (1627), estudio de las múltiples lenguas y castas africanas de los esclavos en Cartagena, es el fruto de un largo proceso interactivo que lleva a Sandoval a ver los cuerpos sufrientes como medios a través de los cuales Dios se comunica con el mundo (196-200). No obstante, el jesuita se empeña en sublimar y superar esta materialidad a fin de reestablecer el orden discursivo católico, de tal modo que termina la obra con una secuencia en que anula esta corporalidad en un espectáculo alegorizante para fundirla en un cuerpo estelar con los santos y mártires que componen el cuerpo místico de Cristo (200-04). De esta manera, Cesareo ve en Sandoval un esfuerzo por restaurar un orden por encima de lo que el jesuita considera ser una situación cultural caótica y conflictiva. Dentro de un espacio que se complica aún más a consecuencia de una mayor profusión de razas, lenguas y culturas, Sandoval desarrolla lo que Cesareo llama "una sensibilidad barroca" para resolver la crisis que surge del fracaso del discurso religioso europeo frente a este mundo de excesos materiales y semióticos (205-08).

El tópico de la crisis de las "castas" coloniales y de sus modos de representación frente a las clases populares se retoma en el ensayo de Sam Cogdell, que se titula "Criollos, gachupines y 'plebe tan en extremo plebe': Retórica e ideología criollas en Alboroto y motín de México de Sigüenza y Góngora". Cogdell estudia el texto de Sigüenza y Góngora 
dentro del contexto histórico de una sociedad estamental que se transforma a raíz de los cambios económicos y del mestizaje étnico y cultural (245-46; 253-54). Analiza la voz doble que el letrado articula frente a esta situación: reivindica los cambios beneficiosos para el grupo criollo a la vez que expresa una actitud de rechazo ante los intereses de los crecientes grupos de mestizos y de indígenas (247-52). Dirigida a un lector simpatizante de la corte madrileña, la carta de Sigüenza y Góngora se compone de acuerdo con el proyecto de convencer a un público peninsular más grande y de demostrar la autoridad intelectual del autor en los asuntos novohispanos. Según Cogdell, para realizar esta tarea el criollo invoca la figura de un "nosotros" por medio de la cual se muestra solidario con los intereses del Estado, narrando los hechos del disturbio de 1692 como si resultaran de una serie de circunstancias adversas que se impusieron a pesar de los esfuerzos diligentes del virrey (254-64). Cogdell observa que en el mismo mes del tumulto, Sigüenza y Góngora recomienda al virrey que promueva el retorno a la estructura urbana establecida por Cortés, según la cual la ciudad de México se había dividido en dos barrios separados, uno español, el otro indígena (265-67). El crítico norteamericano demuestra que esta sugerencia indica la incapacidad de Sigüenza y Góngora, en tanto criollo, para reconocer la realidad de una sociedad cada día más heterogénea que traspasa y rompe el esquema del orden colonial (268).

Los ensayos reunidos en Celestina's Brood y Relecturas del Barroco de Indias traen aportes importantes al estudio del Barroco hispánico. No obstante, es pertinente mencionar ciertos problemas que han surgido de nuestra lectura. Por encima de todo, nos parece que el libro de González Echevarría no alcanza la unidad pretendida en la medida que carece de un pensamiento teórico lo suficientemente matizado de la historia del concepto y de la estética barrocos. Aunque es de admirar el esfuerzo que hace por estudiar el Barroco español y latinoamericano no como entes separados sino como partes de una misma formación discursiva, existen lagunas significativas en su esquema. Primero, su reflexión no toma en consideración una serie de estudios recientes importantes dentro de la historiografía existente sobre el Barroco español - sobre todo, La cultura del Barroco de José Antonio Maravall, Drama of a Nation de Walter Cohen, Contradictory Subjects de George Mariscal, The Body Hispanic de Paul Julian Smith, y las colecciones interdisciplinarias Culture and Control in Counter-Reformation Spain, editada por Anne J. Cruz y Mary Elizabeth Perry, y Literature Among Discourses, editada por Wlad Godzich y Nicholas Spadaccini. Maravall aparece sólo como el autor de El mundo social de "La Celestina" en una nota (239, n.1), pero nombrado curiosamente Juan Antonio Maravall e identificado por González Echevarría como marxista - algo que haría a este maestro de la sociología weberiana revolverse en su tumba. En segundo lugar, no logra ahondar en el tema del papel contradictorio que ha jugado la estética barroca en la Colonia al haber sido a la vez un aparato del poder imperial y un instrumento a través del cual se articula lo que Moraña llama una "conciencia criolla", problemática tratada con profundidad en Relecturas del Barroco de Indias. De hecho, González Echevarría articula una posición historiográfica no marginal - como sostiene él- sino hegemónica, que considera el Barroco como un discurso liberador, precursor de la esfera estética autónoma hacia la cual avanza inevitablemente su libro a través de los estudios sobre Carpentier, Guillén y Sarduy. Se revela así como portador de la ideología estética del modernism, la cual le permite 
conceptualizar la literatura únicamente como una esfera autónoma, separada de la praxis, y desde la cual es posible desmantelar las normas fijadas por el ámbito social. El desarrollo de la genealogía de González Echevarría deriva de la supresión del análisis del papel que han jugado los modos de expresión barrocos en los procesos de exclusión y control de grupos marginales, sobre todo en la Colonia.

La teleología idealista y utópica de González Echevarría también se hace posible gracias a otra postura, relacionada con los límites de un tipo de crítica donde se reproduce la versión formalista del esquema derrideano diseminada por Paul de Man en Estados Unidos, esto es, una especie de desconstrucción descontextualizada. Resulta curioso que el autor declare que siente afinidad con Foucault por interesarse en el análisis de los discursos, puesto que su celebración transhistórica del Barroco tiende a borrar la conciencia que desarrolló el francés en torno al poder que consolidan las instituciones - como la literatura- al manejar los discursos en relación a la praxis social, problemática que discierne Beverley. Como nos hacen recordar muchos de los ensayos contenidos en Relecturas del Barroco de Indias, el buen manejo del estilo gongorino era un arte que le facilitaba al letrado el acceso al aparato administrativo del Estado colonial. Una reflexión mayor sobre este tipo de problemática en el área de la literatura obligaría a González Echevarría a cuestionar si realmente la literatura barroca se define al socavar los discursos autorizados, o si, más bien, forma parte de estos mismos discursos al servir como componente de una red de poder.

Otro problema que ambos libros hacen resurgir es el de la mutación histórica mediante la cual se pasa del humanismo renacentista hacia los desbordes del Barroco. La investigación de las coyunturas coloniales nos exige ir más allá de la descripción de los cambios formales -el paso de la mímesis clásica a las complejidades expresionistas del Culteranismo y del Conceptismo- o del enfoque sobre tópicos de "contenido", como el sentimiento del desengaño que emerge frente a los problemas que sufre España a raíz de la aventura del imperio. Es una situación particular que requiere un lente crítico desde el cual no se consideren las letras y su coyuntura sociohistórica como esferas separadas. Para el caso español, la comedia lopesca, por ejemplo, al transgredir las tres unidades no sólo opera por efecto de la irrupción de la materialidad de las masas en la producción del sentido sino también en tanto aparato mediante el cual se restaura un orden sobre la plebe. En América, la evolución de las formas de expresión que se caracterizan por transmitir un complicado nivel de la híbridez lingüistica y étnica corresponde también a la historia de los encuentros que se realizan entre los géneros humanistas y cristianos, por un lado, y una serie de realidades indígenas heterogéneas, por el otro. La mezcla que surge a raíz de estos encuentros sirve a menudo como un medio de expresión para los sujetos americanos. No obstante, vista desde otro ángulo, también puede reconfigurarse, en tanto formación discursiva más sofisticada y, según parece, más abierta a la otredad, como nuevo mecanismo de control mediante el cual se restablece un orden represivo. Éste es el fenómeno que observan Cesareo, Cogdell y Costigan con gran perspicacia al demostrar que el acto de incorporar una presencia indígena, mestiza o negra a la práctica literaria puede funcionar como una estrategia para constreñir el protagonismo social de estos grupos, no sólo en los escritos españoles y portugueses sino también en los textos criollos. 
Ambos libros apuntan, aunque de manera distinta, hacia el agotamiento de la tesis de una esencia cultural latinoamericana barroca, tesis que depende de la reconstrucción metonímica de una genealogía que liga la estética y la ideología de la Vanguardia con los giros heterodoxos del Culteranismo y del Conceptismo y, al mismo tiempo, con ciertas formas "complicadas" de los modos de expresión prehispánicos. Moraña, Sabat-Rivers, Chang-Rodríguez, Rodríguez Garrido, Sandoval y Costigan han penetrado más allá del andamiaje idealista de dicha tesis al deslindar los mecanismos mediante los cuales los criollos asimilan el estilo gongorino para proyectar esquemas culturales que expresan más fielmente las realidades plurilingüístas y multiétnicas del mundo colonial. No obstante, también se disciernen las normas clasistas y racistas que suelen fijar los autores criollos en sus obras de acuerdo con sus propios programas sociopolíticos, fenómeno que demuestra que el discurso del Barroco americano no articula sencillamente un espacio utópico de liberación y experimentación social e intelectual.

Como afirma Moraña, el Barroco constituye la primera formación discursiva a través de la cual se articula la diferenciación criolla con los modelos culturales españoles y portugueses (i; iv). Sin embargo, resulta pertinente agregar que los discursos de la diferencia en la América colonial no sólo emergen dentro de los parámetros de la "ciudad letrada" virreinal. Primero, cabe pensar en los variados modos de expresión indígena que sobreviven a los efectos de la Conquista y de la evangelización y que no cuadran muy bien dentro del marco formal del Barroco. En segundo lugar, también vale preguntarse si enfatizar tanto el concepto del Barroco significa aplicar, de modo burdo y mecánico, un esquema histórico europeo - el de una dialéctica en que se enfrenta interminablemente en una especie de "modernidad obsoleta" (la expresión es de Beverley) la cultura de la Contrarreforma con la de la Ilustración y la del empiricismo que surge con las trayectorias de los estados nacionales burgueses de Norteamérica y del Norte de Europa- a una serie de coyunturas que se desarrollan de acuerdo con una lógica distinta, más ambigua.

Si se cuestiona el uso de dicho esquema se presenta la posibilidad de que sea necesario repensar las maneras en que los letrados criollos empiezan a armar esa conciencia diferenciada de que se habla en Celestina's Brood y Relecturas del Barroco de Indias. De este modo, se ofrecen al investigador por lo menos dos caminos. En primer lugar, quedan por deslindarse los límites y los márgenes que se esconden detrás de la textualidad heterogénea y confusa del Barroco americano. En segundo lugar, puede postularse una alternativa al gesto de privilegiar el Barroco y la ilustración como conceptos a priori, como puntos de partida. Un paso en esa dirección sería analizar el proceso concreto a través del cual los criollos construyen una conciencia diferenciada, valiéndose de formaciones discursivas variadas - de que el Culteranismo y la escolástica barrocos serían sólo partes. El concepto de "la historiografía criolla" que Ross propone utilizar para describir la escritura de Sigüenza y Góngora parece constituir un esfuerzo valioso por llevar a cabo semejante replanteamiento del marco de estudio.

De acuerdo con la reformulación de los términos del análisis, se enfocaría en el estudio sobre la relación entre poder y producción de conocimientos en la Colonia. De este modo, se investigarían los procesos mediante los cuales los letrados criollos van armando conjuntos de textos y de conocimientos a base de los recursos heterogéneos que les ofrecen las coyunturas americanas plurilingüístas y multirraciales, con el fin de adquirir la legitimidad 
y el poder intelectual para una clase criolla cuyos intereses socioeconómicos se diferencian cada vez más de los de la corona española (y también de los de las clases y de los grupos étnicos subalternos). Tal gesto no supone suprimir la problemática del "Barroco de Indias". Significa, más bien, subsumirla dentro de un proyecto que quizás nos llevaría a un mayor entendimiento de las dinámicas socioculturales no sólo del virreinato sino también de los estados nacionales latinoamericanos desde la Independencia. 